\title{
Evaluation of 2 different treatment procedures after calving to improve harvesting of high-quantity and high-quality colostrum
}

\author{
F. Sutter, ${ }^{1}$ S. Borchardt, ${ }^{1}$ G. M. Schuenemann, ${ }^{2}$ E. Rauch,${ }^{3}$ M. Erhard, ${ }^{3}$ and W. Heuwieser ${ }^{1 *}$ \\ ${ }^{1}$ Clinic for Animal Reproduction, Faculty of Veterinary Medicine, Freie Universität Berlin, Koenigsweg 65, 14163 Berlin, Germany \\ ${ }^{2}$ Department of Veterinary Preventive Medicine, The Ohio State University, Columbus 43210 \\ ${ }^{3}$ Department of Veterinary Sciences, Chair of Animal Welfare, Ethology, Animal Hygiene and Animal Husbandry, Faculty of Veterinary Medicine, \\ Ludwig Maximilian University of Munich, Veterinärstraße 13, 80539 Munich, Germany
}

\section{ABSTRACT}

The objective of this study was to evaluate 2 different treatment procedures at the first milking after calving to increase colostrum quantity and to improve colostrum quality in dairy cows. We hypothesized that either exogenous treatment with oxytocin or the presence of the calf at first milking would lead to higher colostrum quantity and higher IgG concentration. The study was conducted from October to December 2017 on a commercial dairy farm in Germany. A total of 567 cows at the time of calving were enrolled, but for the final analyses only 521 animals were considered. The cows were randomly assigned on a daily basis into 1 of 3 groups: (1) control group $(\mathrm{n}=177),(2)$ application of $20 \mathrm{IU}$ of oxytocin i.m. (OXY; $\mathrm{n}=163$ ), and (3) presence of the calf $(\mathrm{CA} ; \mathrm{n}=181)$ before and during milking. Cows in the control and oxytocin group had no contact with their calves after calving and were milked in a separate milking parlor. Cows in the oxytocin group were injected with $20 \mathrm{IU}$ of oxytocin i.m. 3 min before manual stimulation. For cows in the third group, the calf was placed into a calf cart and located in front of the cow 3 min before manipulation of the cow. Colostrum quantity was determined by a digital hanging scale. The colostrum quality was assessed with digital Brix refractometry and ELISA. To evaluate the effect of 2 different treatment procedures, a generalized linear mixed model was constructed using SPSS (SPSS Inc., IBM, Ehningen, Germany). The mean ( \pm SE) colostrum quantity was $4.17 \pm 0.30 \mathrm{~kg}$. The treatment procedures and the harvesting time after calving had no effect on colostrum quantity. Parity, calf birth weight, and calving time affected colostrum quantity. Cows in second parity had the lowest quantity of colostrum $(3.74 \pm 0.37 \mathrm{~kg})$ compared with cows in parity 1 (4.75

Received February 21, 2019.

Accepted June 8, 2019.

*Corresponding author: w.heuwieser@fu-berlin.de $\pm 0.34 \mathrm{~kg})$ and cows in parity 3 or greater $(4.75 \pm 0.38$ $\mathrm{kg})$. Cows calving during the night $(2200$ until $0600 \mathrm{~h}$; $4.93 \pm 0.37 \mathrm{~kg}$ ) had the highest quantity of colostrum compared with cows calving in the morning (0600 until $1400 \mathrm{~h} ; 4.17 \pm 0.38 \mathrm{~kg}$ ) or afternoon (1400 until 2200 $\mathrm{h} ; 4.14 \pm 0.34 \mathrm{~kg}$ ). Regarding colostrum quality, $48 \%$ of the colostrum samples contained $\geq 50 \mathrm{mg}$ of $\mathrm{IgG} / \mathrm{mL}$. The mean $\mathrm{IgG}$ concentration was $54.6 \pm 2.80 \mathrm{mg}$ of $\mathrm{IgG} / \mathrm{mL}$. Colostrum quality was affected by the treatment procedures, colostrum quantity, parity, calving time, harvesting time after calving, and the calving day during the week. Both treatment procedures (i.e., OXY with mean $\mathrm{IgG}$ concentration results of $57.0 \mathrm{mg}$ of $\mathrm{IgG} / \mathrm{mL}$ and CA with $56.0 \mathrm{mg}$ of $\mathrm{IgG} / \mathrm{mL}$ ) resulted in higher $\operatorname{IgG}$ concentrations in colostrum compared with the control group (50.7 mg of $\mathrm{IgG} / \mathrm{mL}$ ). With increasing colostrum quantity, the colostrum quality decreased in primiparous and multiparous cows. A longer time lag between calving and milking negatively affected the colostrum quality. Concentration of IgG was higher for cows in parity 3 or greater $(64.6 \pm 2.59 \mathrm{mg}$ of $\mathrm{IgG} /$ $\mathrm{mL})$ compared with cows in parity $1(48.5 \pm 2.86 \mathrm{mg}$ of $\mathrm{IgG} / \mathrm{mL})$ and cows in parity $2(50.7 \pm 2.89 \mathrm{mg}$ of $\mathrm{IgG} /$ $\mathrm{mL}$ ). Cows calving during the night had greater IgG concentrations $(60.4 \pm 2.92 \mathrm{mg}$ of $\mathrm{IgG} / \mathrm{mL})$ compared with cows calving in the morning $(51.9 \pm 2.98 \mathrm{mg}$ of $\mathrm{IgG} / \mathrm{mL})$ or afternoon $(51.3 \pm 2.71 \mathrm{mg}$ of $\mathrm{IgG} / \mathrm{mL})$. Harvesting colostrum on quieter days, such as Sundays, resulted in higher IgG concentrations $(61.4 \pm 3.70 \mathrm{mg}$ of $\mathrm{IgG} / \mathrm{mL}$ ). The assessment by Brix refractometry resulted in a mean result of $26.0 \pm 0.20 \%$ Brix. Treatment procedures and the harvesting time after calving had no effect on colostrum quality. A negative association was observed between colostrum quantity and quality in primiparous and multiparous cows determined by Brix refractometry. Brix readings were greater for cows in parity 3 or higher $(27.7 \pm 0.26 \%$ Brix $)$ compared with cows in parity $1(25.3 \pm 0.30 \%$ Brix $)$ and cows in parity $2(25.0 \pm 0.32 \%$ Brix $)$. In conclusion, the treatment procedure for the first milking is irrelevant 
to improve the quantity of colostrum. Both treatment procedures, however, increased IgG concentrations as determined by ELISA.

Key words: dairy cow, colostrum management, colostrum quality, colostrum quantity, oxytocin, calf

\section{INTRODUCTION}

Management and nutrition of the newborn calf during the first hours of life have the potential to permanently affect the lifetime performance of a dairy cow (Faber et al., 2005; Soberon et al., 2012). The role of colostrum in supplying $\operatorname{IgG}$ to the neonatal calf has been well described (Weaver et al., 2000; Godden, 2008). It is known that the timely delivery of colostrum, colostrum quality and quantity, and rate and amount of intestinal IgG absorption are essential components to guarantee a successful passive transfer in calves (Godden, 2017; Kertz et al., 2017). To achieve these goals, it is important to harvest a sufficient quantity of high quality colostrum. Release of oxytocin is the prerequisite for milk ejection and complete colostrum harvest. A continuous ejection of colostrum is dependent on the presence of adequate circulating oxytocin concentration (Wellnitz and Bruckmaier, 2001).

Milk ejection is an innate neuroendocrine reflex, which involves the hypothalamus, pituitary gland, and sensory neurons in the teat. In neurosecretory terminals of the pituitary gland, oxytocin is stored and emptied into the bloodstream upon successful stimulation (Bruckmaier and Blum, 1996; Tančin et al., 2001; Mačuhová et al., 2004). Tactile stimulation of the teats results in the release of oxytocin and causes the contraction of myoepithelial cells around the mammary alveoli, whereby the alveolar milk fraction can be removed (Bruckmaier and Blum, 1998; Tančin et al., 2001). While tactile stimulation of the teats is the primary sensory impulse for milk ejection, genital stimulation and the presence of the newborn calf are also potent stimuli for oxytocin release (Bruckmaier and Blum, 1998; Tančin et al., 2001). Furthermore, it was shown that the presence of the calf during machine milking could influence the release of oxytocin and milk ejection (Akers and Lefcourt, 1982; de Passillé et al., 1997; Lupoli et al., 2001).

The objective of this study was to evaluate 2 different treatment procedures at the first milking after calving to increase colostrum quantity and improve colostrum quality by applying exogenous oxytocin or to stimulate endogenous oxytocin secretion. We hypothesized that either exogenous treatment with oxytocin or the presence of the calf at first milking leads to higher colostrum quantity and higher IgG concentration.

\section{MATERIALS AND METHODS}

\section{Dairy Farm, Animals, and Milking}

This study was conducted from October to December 2017 on a commercial dairy farm in Mecklenburg-Vorpommern, Germany, milking approximately 2,500 Holstein cows. The average annual milk yield was 11,000 $\mathrm{kg} /$ cow. From drying off to the first 20 DIM, cows were housed in a naturally ventilated transition management facility providing freestall barns bedded with sand and ad libitum access to feed and water. Heifer and cow pens had 36 and 144 stalls, respectively. Cows were fed a TMR diet once daily consisting of corn silage and grass silage as forage with corn and canola-meal based concentrate formulated to meet or exceed the dietary requirements for dry and lactating Holstein cows (NRC, 2001). The approximate intake of MP was estimated at $1,189 \mathrm{~g} / \mathrm{d}$. All prepartum cows were vaccinated during the dry period and prepartum heifers before the first calving to improve colostrum quality. The vaccination against Escherichia coli, bovine rotavirus, and coronavirus (Rotavec Corona, MSD Animal Health, Intervet Deutschland GmbH, Unterschleißheim, Germany) was carried out 3 to 12 wk before calving. Postpartum cows were milked 3 times daily (0600, 1400, and $2200 \mathrm{~h}$ ).

\section{Calving Management}

Pregnant heifers and cows were moved on a weekly basis to the prepartum pen $21 \mathrm{~d}( \pm 5)$ before expected parturition. Prepartum cows and heifers were monitored every $30 \mathrm{~min}$ to detect signs of imminent parturition (i.e., restlessness, vaginal discharge with bloody traces, lying lateral with abdominal contractions, a visible or broken amniotic sac, or feet of the emerging calf outside the vulva). Animals were moved into an individual maternity pen $(3.5 \times 3.5 \mathrm{~m})$ bedded with fresh straw when the amniotic sac was visible or broken outside the vulva, or appearance of feet of the emerging calf were detected outside the vulva. A vaginal examination was conducted in every animal transferred to the maternity pen to assess dilatation of the vulva and cervix, as well as position, posture, presentation, and vitality of the calf. If the cow had not delivered the calf $1 \mathrm{~h}$ after the appearance of the amniotic sac or calf feet outside the vulva, calving assistance was provided to reduce calf losses (Schuenemann et al., 2011). Intensity of calving assistance was recorded using a 4-point scale (0 $=$ calving in the prepartum pen; $1=$ no assistance; 2 = assistance by 1 person; $3=$ assistance by at least 2 persons). Twins, caesarean sections, and stillbirths were recorded separately. 
For vaginal examination and calving assistance, cows were restrained in headlocks. The cow's perineum was thoroughly cleaned using warm water and a 10\% tincture of iodine solution (Braunol, B. Braun Melsungen AG, Melsungen, Germany). Lubricant (MS Lubricant, MS Schippers GmbH, Kerken, Germany) was applied generously to the obstetrical gloves and the cow's vagina before performing the exam or providing assistance. After calving, calves were separated from their dam before any suckling occurred. Calves were weighed with an electronic scale (WA200 mobile platform scale, Meier-Brakenberg GmbH \& Co. KG, Extertal, Germany). All newborn calves had their navels dipped using a $10 \%$ tincture of iodine solution (Braunol, B. Braun Melsungen AG) and were placed into a hutch $(1.5 \times$ $1 \mathrm{~m}$ ) bedded with fresh straw for the first $24 \mathrm{~h}$ following birth. Approximately $30 \mathrm{~min}$ after calving, $4 \mathrm{~L}$ of pasteurized (Perfect Udder, Dairy Tech Inc., Greeley, $\mathrm{CO}$ ), pooled, high quality colostrum were fed using an esophageal tube feeder (Dairymac Drencher, Dairytop, Beilen, the Netherlands). Colostrum containing $\geq 22 \%$ Brix was regarded as high quality colostrum (Bielmann et al., 2010). Calves were identified using a 12-digit unique ear tag. Cows had no visual contact with their calves once they were removed from the maternity pen except for cows allocated to group 3 (presence of the calf).

\section{Animal Enrollment and Harvest of Colostrum}

Primiparous and multiparous cows $(\mathrm{n}=567)$ at the time of calving had to meet the following specific inclusion criteria (i.e., clinically healthy, unchanged colostrum, correct assignment to 1 of 3 groups according to the randomization plan) and exclusion criteria (i.e., milk fever, lame cows, bloody or mastitic colostrum, gestation length $<265 \mathrm{~d}$, cows with birth of twins or caesarean section or fetotomy) to be enrolled or withdrawn, respectively. Forty-six animals were excluded due to multiple reasons. For the final analyses, 521 animals (365 multiparous cows and 156 first-calf heifers) were considered.

Prepartum dams were randomly assigned on a daily basis into 1 of 3 treatment procedures to harvest colostrum: (1) control group (CON, $\mathrm{n}=177)$, (2) oxytocin group (OXY, $\mathrm{n}=163$ ) with application of $20 \mathrm{IU}$ of oxytocin, and (3) presence of the calf before and during milking (CA, $\mathrm{n}=181$ ). Before initiation of the study, a list of prepartum dams was created to assign 1 of the 3 treatment procedures to a specific calving date using a random function of Excel (Office 2010, Microsoft Deutschland Ltd., Munich, Germany). During 24 h each calving was subjected to the treatment procedure, which was assigned to that specific day by the Excel list. Each treatment procedure (CON, OXY, or CA) was performed for a total of 28 nonconsecutive days.

Cows were placed in a self-locking chute immediately after parturition to harvest colostrum. Teats were predipped, forestripped, and dry wiped using a clean paper towel. Forestripping included the manual removal of 2 streams of colostrum from each teat. Manual stimulation lasted $30 \mathrm{~s}$. The lag time between manual stimulation and attachment of the milk unit clusters was $60 \mathrm{~s}$. The vacuum of the milking equipment (Flo-Star MAX, Boumatic Robotics GmbH, Kempten, Germany) was $45 \mathrm{kPa}$ and the milk-to-rest ratio was at 60:40. After milking, the teats of the cows were dipped (Jod 5000, CID Lines N.V., Ieper, Belgium). A vaginal obstetrical follow-up examination was conducted to identify vaginal injuries or the presence of a second calf. All postpartum cattle received $150 \mathrm{~mL}$ of propylene glycol orally after milking. All multiparous cows received an oral calcium bolus (Bovikalc, Boehringer Ingelheim Vetmedica GmbH, Ingelheim am Rhein, Germany).

Cows in the CON group had no contact with their calves after removal from the maternity pen and were milked as described above. Cows in the OXY group had no contact with their calves after removal from the maternity pen, but were injected with $20 \mathrm{IU}$ of oxytocin (Oxytocin ad us. Vet., aniMedica GmbH, Senden-Bösensell, Germany) i.m. (BMV injection syringe and MS Alu-Hub cannula $1.2 \times 16 \mathrm{~mm}$, MS Schippers GmbH, Kerken, Germany) into the neck region 3 min before manual stimulation. Milking occurred as described above. For cows in the third group (CA), the calf was placed into a calf cart and located in front of the cow 3 min before manipulation of the cow and during the whole milking process.

Colostrum was harvested into a bucket weighing $3.48 \mathrm{~kg}$. After each milking the bucket, including the colostrum, was weighed with a digital hanging scale (digital hanging scale, model no. XY-2003, Etekcity Corporation, Anaheim, CA, minimum weight $200 \mathrm{~g}$, and maximum weight $50 \mathrm{~kg}$ ) and then the weight of the bucket was subtracted. A colostrum sample (15 $\mathrm{mL}$ ) was collected into a sterile plastic container (15$\mathrm{mL}$ centrifuge tubes with screw caps, Carl Roth $\mathrm{GmbH}$ + Co. KG, Karlsruhe, Germany) and frozen $\left(-20^{\circ} \mathrm{C}\right)$ until further analysis. Colostrum quality was assessed using a digital Brix refractometer (HI 96801, Hanna Instruments Deutschland GmbH, Vöhringen, Germany) by farm personnel and the first author. Frozen colostrum samples were stored on ice for transportation to laboratory of the Clinic of Animal Reproduction. Time between sampling of cows and pick-up to laboratory delivery never exceeded $7 \mathrm{~d}$. 


\section{Colostrum Sample Analysis}

For further assessment, the colostrum samples were thawed at ambient temperature until reaching $21^{\circ} \mathrm{C}$, vortexed for $10 \mathrm{~s}, 1-\mathrm{mL}$ aliquot was transferred to a sterile vial (Cryovial $2 \mathrm{~mL}$; Simport, Bernard-Pilon, Germany) and shipped on ice to the Veterinary Science Department, Faculty of Veterinary Medicine, Ludwig Maximilian University of Munich, for $\operatorname{IgG}$ analysis.

The IgG in the colostrum was measured using a sandwich ELISA according to Erhard et al. (1999). Samples were diluted with PBS-Tween in a ratio of 1:50,000. The detection of the IgG concentration was based on coating and conjugating the $\operatorname{IgG}$ with anti-bovine IgG coupled to a peroxidase enzyme, which catalyzed a color change proportional to the $\operatorname{IgG}$ concentration of the sample. This color change was measured photometrically. Rabbit serum with anti-bovine IgG $(5 \mu \mathrm{g} / \mathrm{mL}$; A 5645, Sigma-Aldrich Chemie GmbH, Taufkirchen, Germany) was pipetted into each well of a 96-well polystyrene plate (F96 Cert. Maxisorp NuncImmuno Plate, Thermo Scientific GmbH, Darmstadt, Germany) and blocked with a $0.5 \%$ gelatin PBS solution. The diluted colostrum samples were inoculated into the uppermost cavity of each column. In addition, the samples were diluted by using a 2-logarithmic dilution series with PBS-Tween buffer in a ratio of $1: 2$. Furthermore, the peroxidase-linked rabbit anti-bovine $\operatorname{IgG}$ and the substrate solution $(332 \mu \mathrm{L}$ of stock solution, $10 \mathrm{~mL}$ of tetramethylbenzidine buffer, $30 \% \mathrm{H}_{2} \mathrm{O}_{2}$ ) were added, which started the enzyme reaction. By applying $50 \mu \mathrm{L}$ of 1 molar sulfuric acid, the reaction process was stopped. The photometric intensity was measured at $450 \mathrm{~nm}$ with an ELISA Reader (GENios, Tecan Germany GmbH, Crailsheim, Germany). The mean value of the $\mathrm{IgG}$ concentration in each well of one column resulted in the final colostrum concentration (mg of IgG/mL). Colostrum containing $\geq 50 \mathrm{mg} / \mathrm{mL}$ of IgG was regarded as high quality colostrum (McGuirk and Collins, 2004).

\section{Data Collection and Statistical Analyses}

Relevant cow data such as cow ID, parity, gestation length, days in the prepartum pen, calving ease, date and time of parturition, calf birth weight, sex of calf, twin births, and postpartum diseases (e.g., milk fever, retained fetal membranes, metritis) were obtained through the on-farm computer software (DairyCOMP 305, Valley Ag Software, Tulare, CA) and transferred to Microsoft Excel (Office 2013, Microsoft Deutschland Ltd.). Statistical analyses were performed using SPSS for Windows (version 22.0, SPSS Inc., IBM, Ehningen, Germany).
A priori sample size was calculated using MedCalc software (version 15.6.1, MedCalc, Mariakerke, Belgium). Based on historical data from the farm regarding colostrum quantity $(5.8 \pm 2.9 \mathrm{~kg})$, the sample size was calculated to detect an increase in colostrum quantity of $1.0 \mathrm{~kg}$, assuming $80 \%$ power and a confidence level of $95 \%$. Therefore, a total of 133 dairy cows per group were needed.

To evaluate the effect of 2 different treatment procedures to increase colostrum quantity and quality, 2 separate generalized linear mixed models were constructed using the GENLINMIXED procedure of SPSS. The outcome variable was either colostrum quantity $(\mathrm{kg})$ or quality ( $\mathrm{mg}$ of $\mathrm{IgG} / \mathrm{mL}$ or \% Brix). Cow was the experimental unit. According to the model-building strategies described by Dohoo et al. (2009), each parameter considered for the mixed model was separately analyzed in an univariate model, including the parameter as a fixed factor (i.e., categorical parameter) or covariate (i.e., continuous parameter). Only parameters resulting in univariate models with $P \leq 0.20$ were included in the final mixed model. Selection of the model that best fit the data was performed by testing each effect separately in a multivariate model and finding the model with the lowest value for the Akaike information criterion using a backward elimination procedure that removed all variables with $P>0.10$ from the model. Regardless of the significance level, the intervention procedure was forced to remain in the model.

The initial model for colostrum quantity contained the following explanatory variables as fixed effects: treatment procedure (CON, OXY, and CA), parity (1, 2 , and $3+$ ), calving ease (score 1 to 4 ), employee responsible for calving and milking ( 1 to 8), calving time (morning from 0600 to $1400 \mathrm{~h}$, afternoon from 1400 to $2200 \mathrm{~h}$, night from 2200 to $0600 \mathrm{~h}$ ), calving time during the day (1 to $24 \mathrm{~h}$ ), calving day of the week (Monday until Sunday), harvesting time after calving (hours; continuous), calf sex (male vs. female), calf birth weight (continuous), gestation length (continuous), and days in the prepartum pen (continuous).

The initial model for colostrum quality contained the same explanatory variables as for colostrum quantity. Additionally, colostrum quantity (continuous) was included. We tested all biologically plausible 2-way interactions.

Correlation coefficients, minima, and maxima were determined using Excel (Office 2010, Microsoft Deutschland Ltd.).

\section{RESULTS}

Overall, 567 animals were enrolled. Forty-six animals were excluded due to multiple reasons such as lameness 


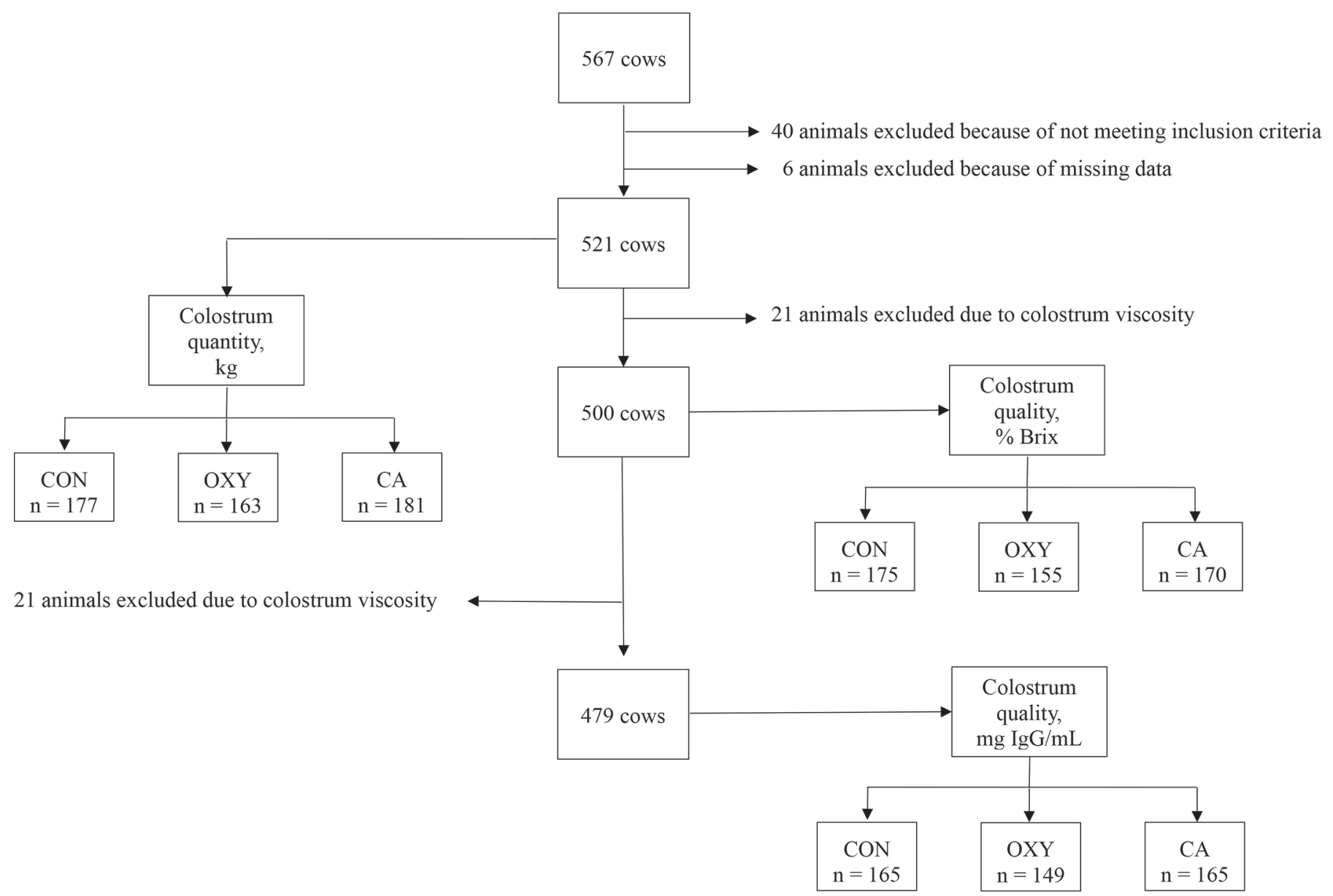

Figure 1. Flowchart of total number of animals enrolled in the study and considered for final analyses. Number of animals included in each analysis might differ due to several reasons (e.g., inclusion criteria were not met, missing data about colostrum quantity and quality, colostrum was too viscous to be considered for sandwich ELISA analysis or Brix refractometry). Cows in the control group (CON) had no contact with their calves after calving. Cows in the oxytocin group (OXY) had no contact with their calves and were injected with 20 IU of oxytocin i.m. 3 min before first milking. In the presence of the calf group (CA), the calf was placed into a calf cart and located in front of the cow 3 min before manipulation of the cow and during the whole milking process.

$(\mathrm{n}=1)$, bloody colostrum $(\mathrm{n}=20)$, mastitic colostrum $(\mathrm{n}=1)$, gestation length of less than $265 \mathrm{~d}(\mathrm{n}=7)$, twin births $(\mathrm{n}=11)$, and missing data $(\mathrm{n}=6)$. For the final analyses, 521 animals (365 multiparous cows and 156 first-calf heifers) were considered regarding colostrum quantity (Figure 1). The mean harvesting time after calving was $47 \pm 0.33 \mathrm{~min}$ with a range of minimum 5 min up to maximum of $4 \mathrm{~h}$ and 50 min after calving.

\section{Colostrum Quantity}

Information on colostrum quantity was available for 177, 163, and 181 animals in the CON, OXY, and CA group, respectively (Figure 1). No differences were observed in parity $(P=0.82)$ or calf birth weight $(P=$ $0.65)$ among the 3 groups. The correlation coefficient of gestation length and calf birth weight was $\mathrm{r}=0.49$. The harvesting time after calving had no significant effect on colostrum quantity $(P=0.33)$. The mean colostrum quantity was $4.17 \pm 0.30 \mathrm{~kg}$ (minimum: 0.00 $\mathrm{kg}$, maximum: $28.40 \mathrm{~kg}$ ). The treatment procedures had no effect on colostrum quantity $(P=0.50$; Table 1 ; Figure 2$)$. Parity $(P=0.01)$, calf birth weight $(P<$ 0.01 ; Figure 2), and calving time $(P=0.08)$ affected colostrum quantity. Parity 2 cows had the lowest quantity of colostrum $(3.74 \pm 0.37 \mathrm{~kg})$ compared with cows in parity $1(4.75 \pm 0.34 \mathrm{~kg})$ and cows in parity 3 or greater $(4.75 \pm 0.38 \mathrm{~kg})$. Cows calving during the night $(4.93 \pm 0.37 \mathrm{~kg})$ had the highest quantity of colostrum compared with cows calving in the morning (4.17 \pm $0.38 \mathrm{~kg})$ or afternoon $(4.14 \pm 0.34 \mathrm{~kg}$; Table 1$)$.

\section{Colostrum Quality Measured by Sandwich ELISA}

Information on colostrum quality was available for 165, 149, and 165 animals in the CON, OXY, and CA 
Table 1. Estimated effect of 2 treatment procedures at the first milking after calving aiming at increasing colostrum quantity $(\mathrm{kg})$ in 521 Holstein dairy cows

\begin{tabular}{|c|c|c|c|c|c|}
\hline \multirow[b]{2}{*}{ Variable } & \multirow{2}{*}{$\begin{array}{c}\text { Estimate } \\
\text { colostrum, kg }\end{array}$} & \multirow[b]{2}{*}{$\mathrm{SE}^{1}$} & \multicolumn{2}{|c|}{$95 \% \mathrm{CI}$} & \multirow[b]{2}{*}{$P$-value } \\
\hline & & & Lower CI & Upper CI & \\
\hline Intercept & -3.595 & 1.20 & -5.953 & -1.237 & 0.003 \\
\hline \multicolumn{6}{|l|}{ Parity } \\
\hline Parity 1 & Referent & & & & \\
\hline Parity 2 & -1.007 & 0.41 & -1.806 & -0.207 & 0.014 \\
\hline Parity $3+$ & 0.008 & 0.39 & -0.758 & 0.775 & 0.983 \\
\hline \multicolumn{6}{|l|}{ Treatment procedure $^{2}$} \\
\hline Control group ${ }^{3}$ & Referent & & & & \\
\hline Oxytocin group ${ }^{4}$ & 0.359 & 0.36 & -0.342 & 1.060 & 0.314 \\
\hline Presence of the calf ${ }^{5}$ & 0.354 & 0.35 & -0.327 & 1.035 & 0.308 \\
\hline \multicolumn{6}{|l|}{ Calving time } \\
\hline Morning (0600 to $1400 \mathrm{~h}$ ) & Referent & & & & \\
\hline Afternoon (1400 to $2200 \mathrm{~h}$ ) & -0.025 & 0.38 & -0.774 & 0.723 & 0.947 \\
\hline Night $(2200$ to $0600 \mathrm{~h})$ & 0.769 & 0.42 & -0.053 & 1.591 & 0.067 \\
\hline Calf birth weight & 0.189 & 0.03 & 0.132 & 0.247 & 0.001 \\
\hline
\end{tabular}

${ }^{1} \mathrm{SE}=$ standard error of the estimate.

${ }^{2}$ Different treatment procedures at the first milking after calving aiming at increasing colostrum quantity $(\mathrm{kg})$ in 521 Holstein dairy cows.

${ }^{3}$ Control group $(\mathrm{n}=177)$ : cows in the control group had no contact with their calves after calving.

${ }^{4}$ Oxytocin group $(\mathrm{n}=163)$ : cows in the oxytocin group had no contact with their calves and were injected with $20 \mathrm{IU}$ of oxytocin i.m. 3 min before first milking.

${ }^{5}$ Presence of the calf group $(\mathrm{n}=181)$ : the calf was placed into a calf cart and located in front of the cow 3 min before manipulation of the cow and during the whole milking process.

group, respectively (Figure 1). Forty-two colostrum samples could not be assessed with sandwich ELISA due to their high viscosity (12 samples in CON, 14 in $\mathrm{OXY}$, and 16 in CA). There was no difference in parity $(P=0.95)$ and calf birth weight $(P=0.51)$ among the 3 groups. The mean IgG concentration was $54.6 \pm 2.80$ $\mathrm{mg}$ of $\mathrm{IgG} / \mathrm{mL}$ (minimum: $14.5 \mathrm{mg}$ of $\mathrm{IgG} / \mathrm{mL}$, maximum: $146.3 \mathrm{mg}$ of $\mathrm{IgG} / \mathrm{mL}$ ). Colostrum quality was affected by the treatment procedures $(P=0.04$; Figure $3)$. In addition, colostrum quantity $(P<0.01)$, parity $(P<0.01$; Table 2; Figure 3$)$, calving time $(P<0.01)$, harvesting time after calving $(P=0.03)$, and calving day $(P=0.06)$ had an effect on the IgG concentration in colostrum. Both treatment procedures [i.e., OXY with mean $\mathrm{IgG}$ concentration results of $57.0 \mathrm{mg}$ of $\mathrm{IgG} /$ $\mathrm{mL}(P=0.02)$ and $\mathrm{CA}$ with $56.0 \mathrm{mg}$ of $\mathrm{IgG} / \mathrm{mL}(P=$ $0.04)$ ] resulted in higher IgG concentrations in colostrum compared with CON (50.7 mg of $\mathrm{IgG} / \mathrm{mL}$ ). With increasing colostrum quantity, the IgG concentration in colostrum $(\mathrm{mg} / \mathrm{mL})$ decreased in primiparous cows $(\mathrm{r}=$ $-0.21)$ and in multiparous cows $(\mathrm{r}=-0.13$; Table 2$)$. A longer time lag between calving and milking negatively affected the IgG concentration in colostrum $(\mathrm{mg} / \mathrm{mL})$. Concentration of IgG was higher for cows in parity 3 or greater $(64.6 \pm 2.59 \mathrm{mg}$ of $\mathrm{IgG} / \mathrm{mL})$ compared with cows in parity $1(48.5 \pm 2.86 \mathrm{mg}$ of $\mathrm{IgG} / \mathrm{mL})$ and cows in parity $2(50.7 \pm 2.89 \mathrm{mg}$ of $\mathrm{IgG} / \mathrm{mL})$. Cows calving during the night had greater IgG concentrations (60.4 $\pm 2.92 \mathrm{mg}$ of $\mathrm{IgG} / \mathrm{mL}$ ) compared with cows calving in the morning $(51.9 \pm 2.98 \mathrm{mg}$ of $\mathrm{IgG} / \mathrm{mL})$ or afternoon $(51.3 \pm 2.71 \mathrm{mg}$ of $\mathrm{IgG} / \mathrm{mL})$. Harvesting colostrum on quieter days, such as Sundays, resulted in higher IgG concentrations $(61.4 \pm 3.70 \mathrm{mg}$ of $\mathrm{IgG} / \mathrm{mL})$.

\section{Colostrum Quality Measured by Brix Refractometry}

Information on colostrum quality measured by Brix refractometry was available for 175,155 , and 170 animals in the CON, OXY, and CA group, respectively (Figure 1). Twenty-one colostrum samples could not be assessed with Brix refractometer due to their high viscosity (2 samples in CON, 8 in OXY, and 11 in CA). The harvesting time after calving had no significant effect on colostrum quality $(P=0.73)$. There was no difference in parity $(P=0.76)$ and no difference in calf birth weight $(P=0.49)$ among the 3 groups. The mean result was $26.0 \pm 0.20 \%$ Brix (minimum: $15.7 \%$ Brix, maximum: $39.7 \%$ Brix). Treatment procedures had no effect on colostrum quality $(P=0.44$; Table 3 ; Figure $3)$. Colostrum quantity $(P<0.01$; Table 3$)$ and parity $(P<0.01$; Table 3 ; Figure 3$)$ affected colostrum quality. A negative association was observed between colostrum quantity and quality determined by Brix refractometry. With increasing colostrum quantity, the Brix readings (\% Brix) decreased. The correlation coefficient was $\mathrm{r}=$ -0.09 in primiparous cows and $\mathrm{r}=-0.17$ in multiparous cows. Brix readings were greater for cows in parity 3 or higher $(27.7 \pm 0.26 \%$ Brix $)$ compared with cows in 
parity $1(25.3 \pm 0.30 \%$ Brix $)$ and cows in parity $2(25.0$ $\pm 0.32 \%$ Brix). The correlation coefficient between the analysis with sandwich ELISA and the assessment via Brix refractometry was $\mathrm{r}=0.44$.

\section{DISCUSSION}

The main findings of the present study were (1) the treatment procedure did not affect colostrum quantity; (2) administration of oxytocin or the presence of the calf increased $\operatorname{IgG}$ concentration in colostrum of cows compared with the control group; (3) parity was associated with colostral IgG concentration; and (4) calf birth weight, calving time, and calving day were positively associated with colostrum quantity. Hence the treatment procedure had no overall effect on colostrum quantity; both treatments were beneficial for IgG concentration in colostrum.

\section{Colostrum Quantity}

There was a negative association of colostrum quantity and quality regardless of the measurement (i.e., sandwich ELISA or Brix refractometry). This is in line with an older study that also reported a negative correlation between colostrum quantity and quality with a correlation coefficient of $\mathrm{r}=-0.29$ (Pritchett et al., 1991). This effect is most likely due to dilution of colostral IgG. The increasing colostrum quantity is based on water diffusion, because of a higher secretion of lactose into the udder when the lactation begins, whereas the absolute amount of IgG remains the same (Baumrucker et al., 2010; Morin et al., 2010).

\section{Colostrum Quality}

Forty-eight percent of the colostrum samples contained $\geq 50 \mathrm{mg}$ of $\mathrm{IgG} / \mathrm{mL}$ and $6.5 \%$ contained $\geq 100 \mathrm{mg}$ of $\operatorname{IgG} / \mathrm{mL}$. The mean $\operatorname{IgG}$ concentration in the present study was $54.6 \pm 24.71 \mathrm{mg}$ of $\mathrm{IgG} / \mathrm{mL}$ with a range of 14.5 to $146.3 \mathrm{mg}$ of $\mathrm{IgG} / \mathrm{mL}$. This is in agreement with a previous study (Baumrucker et al., 2010) in which a range of 9 to $166 \mathrm{mg}$ of $\mathrm{IgG} / \mathrm{mL}$ was reported.

For the comparison of IgG concentration across studies, it is important to consider the analytical methods used. The common techniques were radial immunodiffusion (RID; Kehoe et al., 2011; Rivero et al., 2012) and ELISA (Baumrucker et al., 2010; Nowak et al., 2012). In addition, preparation of colostrum samples varied between studies. Baumrucker et al. (2010) removed the colostral fat before analysis with ELISA, whereas others did not (Morrill et al., 2012). It has been established that removal of colostral fat before the analysis can cause overestimation of IgG concentration using RID (Fleenor and Stott, 1981). Such methodological differences create challenges when comparing results across studies.

Both treatment procedures (OXY and $\mathrm{CA}$ ) were beneficial for colostrum quality. We speculate that both procedures led to a high concentration of oxytocin in the blood, which might have affected the integrity
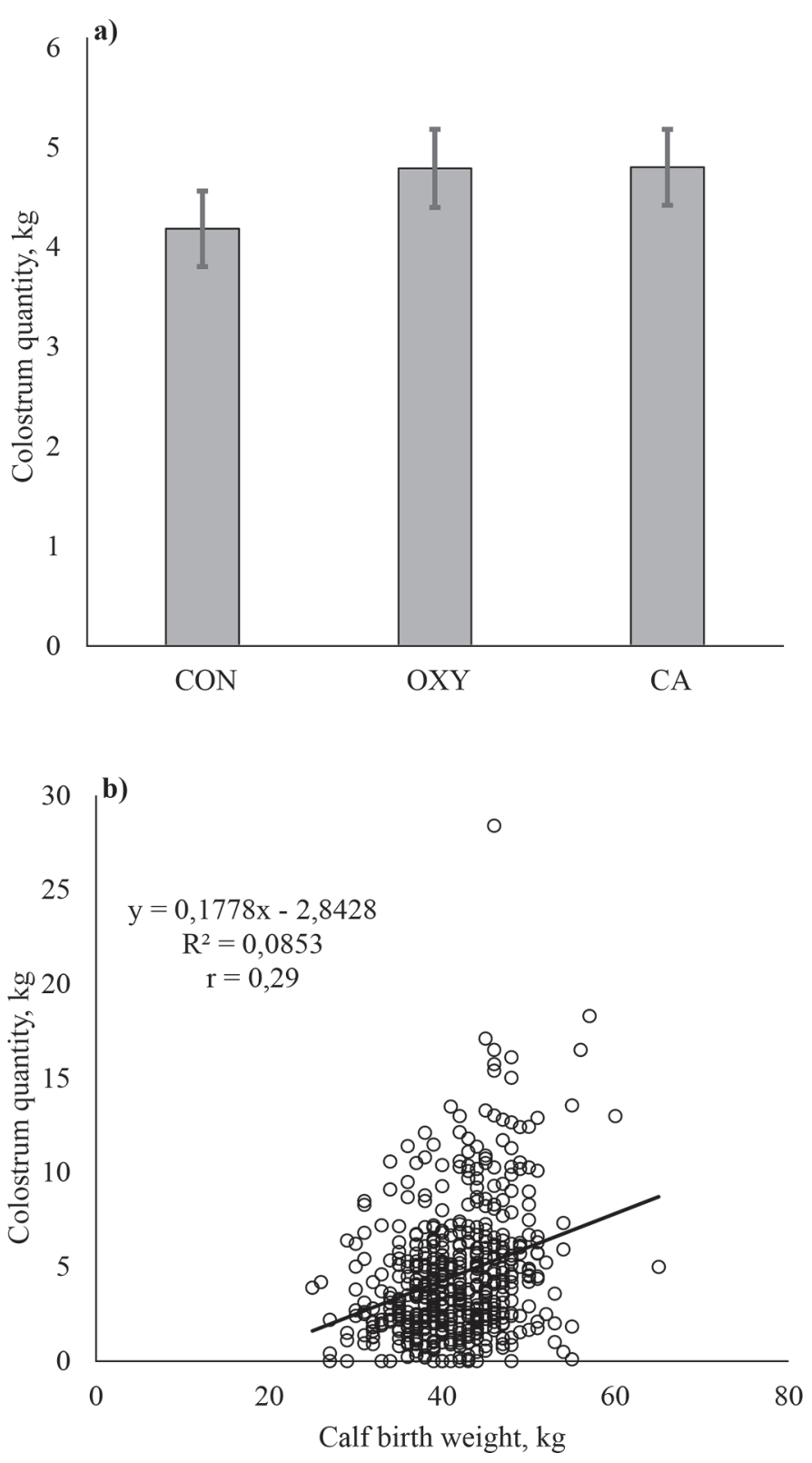

Figure 2. (a) Effect of treatment procedure at harvesting of colostrum on colostrum quantity $(\mathrm{kg}$, means $\pm \mathrm{SE}$ ). Cows in the control group (CON; $\mathrm{n}=177$ ) had no contact with their calves. Cows in the oxytocin group (OXY; $\mathrm{n}=163$ ) had no contact with their calves and were injected with oxytocin (20 IU i.m.) 3 min before first milking. For cows in the presence of the calf group (CA; $n=181)$, the calf was placed into a calf cart and located in front of the cow 3 min before manipulation of the cow and while milking. (b) Effect of calf weight on colostrum quantity. 
a)

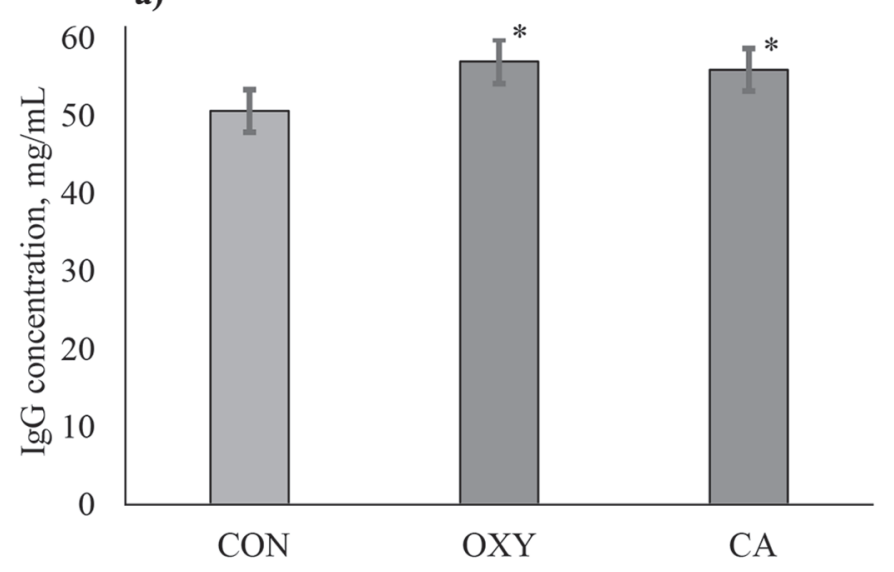

c)

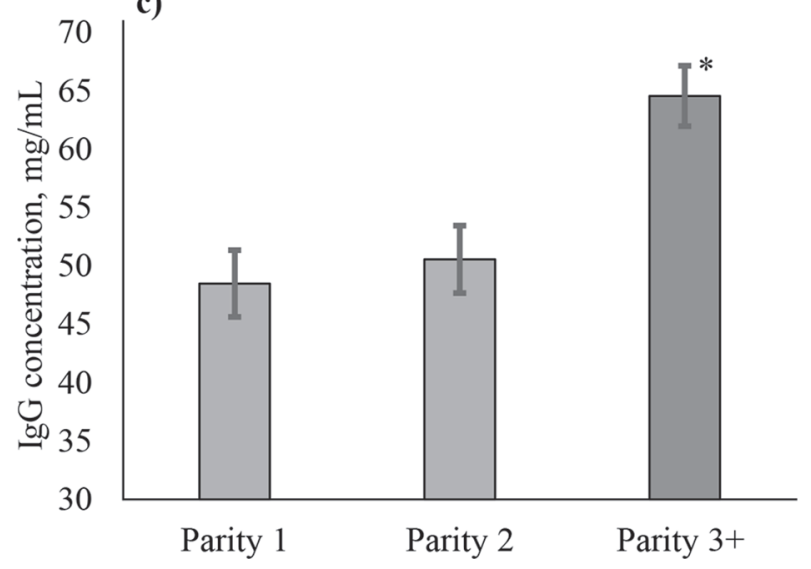

30

b)
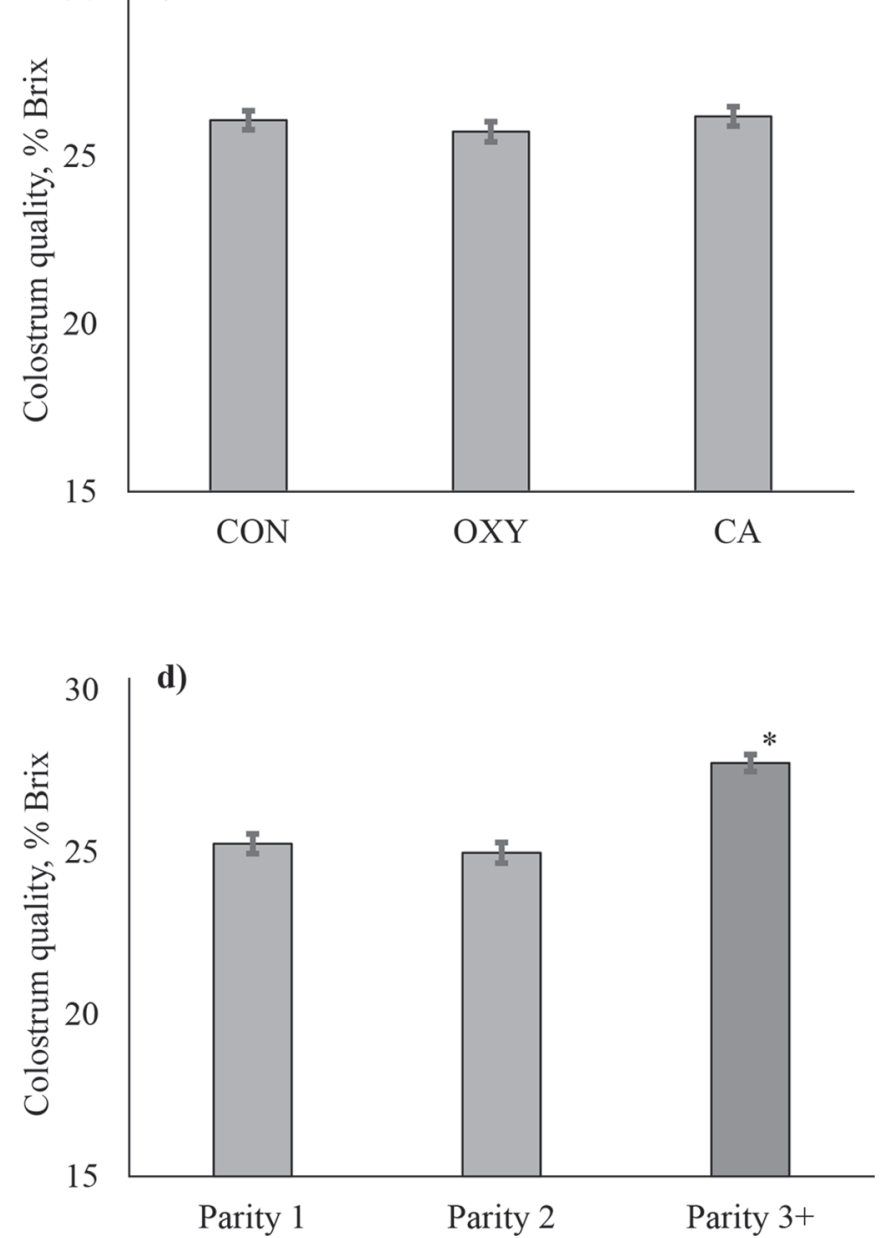

Figure 3. (a) and (b) Effect of different treatment procedures at harvesting of colostrum on colostral IgG concentration (mg/mL, means \pm $\mathrm{SE}$ ) and on colostrum quality in \% Brix (\% Brix, means \pm SE). Different treatment procedures before the first milking have been evaluated to improve harvesting of high quality colostrum. Cows in the control group (CON) had no contact with their calves. Cows in the oxytocin group (OXY) had no contact with their calves and were injected with oxytocin (20 IU i.m.) 3 min before first milking. For cows in the presence of the calf group (CA), the calf was placed into a calf cart and located in front of the cow 3 min before manipulation of the cow and while milking [animals enrolled: (a) CON, $\mathrm{n}=165$; OXY, $\mathrm{n}=149$; CA, n = 165; (b) CON, n = 175; OXY, n = 155; CA, n = 170]. (c) and (d) Effect of parity at harvesting of colostrum on colostral IgG concentration ( $\mathrm{mg} / \mathrm{mL}$, means $\pm \mathrm{SE}$ ) and on colostrum quality in $\%$ Brix (\% Brix, means \pm SE). Different treatment procedures at harvesting the first colostrum have been evaluated to increase colostrum quality. Parity was one of different parameters that were taken into consideration [animals enrolled: (c) cows in parity $1, \mathrm{n}=144 ; \mathrm{parity} 2, \mathrm{n}=130 ;$ parity 3 or greater, $\mathrm{n}=205$; (d) cows in parity $1, \mathrm{n}=149$; parity $2, \mathrm{n}=133$; parity 3 or greater, $\mathrm{n}=218$ ].

of the mammary tight junctions and presumably led to a higher IgG transfer into the udder (Stelwagen and Singh, 2014). According to Stelwagen and Singh (2014) the tight junction integrity of the mammary gland might be compromised following administration of high, nonphysiological, doses of exogenous oxytocin. The increased permeability is likely due to a disruption of the cell-cell contact as a result of the mechanical forces caused by the sudden alveolar contraction (Stelwagen and Singh, 2014).

Another explanation for higher IgG concentrations in OXY and CA might be that the high concentration of exogenous or endogenous oxytocin leads to the removal of residual milk from the udder, which might possibly result in higher IgG concentrations in colostrum. About 15 to $20 \%$ residual milk stays in the udder after milking. Nostrand et al. (1991) found that the use of exogenous oxytocin increased lactation milk production during the declining phase of lactation after peak milk yield. However, mean fat and protein percentages did not differ for oxytocin and control cows during lactation (Nostrand et al., 1991). We could not detect a difference in colostrum quantity for cows receiving exogenous oxytocin (OXY) and presumably a higher endogenous oxytocin concentration (CA) compared with CON cows. 
Table 2. Estimated effect of 2 treatment procedures at the first milking after calving aiming at increasing colostrum quality ( $\mathrm{mg}$ of $\mathrm{IgG} / \mathrm{mL})$ in 479 Holstein dairy cows

\begin{tabular}{|c|c|c|c|c|c|}
\hline \multirow[b]{2}{*}{ Variable } & \multirow{2}{*}{$\begin{array}{c}\text { Estimate colostrum, } \\
\mathrm{mg} \text { of } \mathrm{IgG} / \mathrm{mL}\end{array}$} & \multirow[b]{2}{*}{$\mathrm{SE}^{1}$} & \multicolumn{2}{|c|}{$95 \% \mathrm{CI}$} & \multirow[b]{2}{*}{$P$-value } \\
\hline & & & Lower CI & Upper CI & \\
\hline Intercept & 55.44 & 4.73 & 46.14 & 64.74 & 0.001 \\
\hline \multicolumn{6}{|l|}{ Parity } \\
\hline Parity 1 & Referent & & & & \\
\hline Parity 2 & 2.073 & 2.89 & -3.603 & 7.748 & 0.473 \\
\hline Parity $3+$ & 16.069 & 2.59 & 10.976 & 21.163 & 0.001 \\
\hline \multicolumn{6}{|l|}{ Treatment procedure ${ }^{2}$} \\
\hline Control group ${ }^{3}$ & Referent & & & & \\
\hline Oxytocin group ${ }^{4}$ & 6.351 & 2.73 & 0.986 & 11.716 & 0.020 \\
\hline Presence of the calf ${ }^{5}$ & 5.300 & 2.61 & 0.165 & 10.435 & 0.043 \\
\hline Colostrum quantity & -1.658 & 0.32 & -2.280 & -1.035 & 0.001 \\
\hline \multicolumn{6}{|l|}{ Calving time } \\
\hline Morning (0600 to $1400 \mathrm{~h}$ ) & Referent & & & & \\
\hline Afternoon (1400 to $2200 \mathrm{~h}$ ) & -0.644 & 2.88 & -6.294 & 5.007 & 0.823 \\
\hline Night $(2200$ to $0600 \mathrm{~h})$ & 8.469 & 3.18 & 2.214 & 14.725 & 0.008 \\
\hline Harvesting time, $\mathrm{h}$ & -3.213 & 1.43 & -6.011 & -0.414 & 0.025 \\
\hline \multicolumn{6}{|l|}{ Calving day of the week } \\
\hline Monday & Referent & & & & \\
\hline Tuesday & -5.581 & 3.93 & -13.312 & 2.150 & 0.157 \\
\hline Wednesday & -6.499 & 4.01 & -14.378 & 1.381 & 0.106 \\
\hline Thursday & -4.884 & 3.88 & -12.5036 & 2.735 & 0.208 \\
\hline Friday & -0.994 & 4.16 & -9.166 & 7.178 & 0.811 \\
\hline Saturday & -7.850 & 3.96 & -15.6231 & -0.076 & 0.048 \\
\hline Sunday & 3.714 & 4.16 & -4.464 & 11.892 & 0.373 \\
\hline
\end{tabular}

${ }^{1} \mathrm{SE}=$ standard error of the estimate.

${ }^{2}$ Different treatment procedures at the first milking after calving aiming at increasing colostrum quality (mg of $\mathrm{IgG} / \mathrm{mL})$.

${ }^{3}$ Control group $(\mathrm{n}=165)$ : cows in the control group had no contact with their calves after calving.

${ }^{4}$ Oxytocin group $(\mathrm{n}=149)$ : cows in the oxytocin group had no contact with their calves and were injected with 20 IU of oxytocin i.m. 3 min before first milking.

${ }^{5}$ Presence of the calf group $(\mathrm{n}=165)$ : the calf was placed into a calf cart and located in front of the cow $3 \mathrm{~min}$ before manipulation of the cow and during the whole milking process.

Table 3. Estimated effect of 2 treatment procedures at the first milking after calving to stimulate oxytocin secretion aiming at increasing colostrum quality (\% Brix) in 500 Holstein dairy cows

\begin{tabular}{|c|c|c|c|c|c|}
\hline \multirow[b]{2}{*}{ Variable } & \multirow{2}{*}{$\begin{array}{c}\text { Estimate } \\
\text { colostrum quality, } \\
\% \text { Brix }\end{array}$} & \multirow[b]{2}{*}{$\mathrm{SE}^{1}$} & \multicolumn{2}{|c|}{$95 \% \mathrm{CI}$} & \multirow[b]{2}{*}{$P$-value } \\
\hline & & & Lower CI & Upper CI & \\
\hline Intercept & 26.336 & 0.41 & 25.53 & 27.14 & 0.001 \\
\hline \multicolumn{6}{|l|}{ Parity } \\
\hline Parity 1 & Referent & & & & \\
\hline Parity 2 & -0.279 & 0.40 & -1.061 & 0.504 & 0.485 \\
\hline Parity 3+ & 2.490 & 0.36 & 1.788 & 3.192 & 0.001 \\
\hline \multicolumn{6}{|l|}{ Treatment procedure $^{2}$} \\
\hline Control group ${ }^{3}$ & Referent & & & & \\
\hline Oxytocin group 4 & -0.343 & 0.37 & -1.069 & 0.383 & 0.354 \\
\hline Presence of the calf ${ }^{5}$ & 0.116 & 0.36 & -0.590 & 0.823 & 0.746 \\
\hline Colostrum quantity & -0.215 & 0.04 & -0.302 & -0.128 & 0.001 \\
\hline
\end{tabular}

${ }^{1} \mathrm{SE}=$ standard error of the estimate.

${ }^{2}$ Different treatment procedures at the first milking after calving aiming at increasing colostrum quality (\% Brix).

${ }^{3}$ Control group $(\mathrm{n}=175)$ : cows in the control group had no contact with their calves after calving.

${ }^{4}$ Oxytocin group $(\mathrm{n}=155)$ : cows in the oxytocin group had no contact with their calves and were injected with 20 IU of oxytocin i.m. 3 min before first milking.

${ }^{5}$ Presence of the calf group $(\mathrm{n}=170)$ : the calf was placed into a calf cart and located in front of the cow 3 min before manipulation of the cow and during the whole milking process. 
In previous studies, the correlation between RID and digital refractometry ranged from 0.64 to 0.87 (Vandeputte et al., 2014; Bartier et al., 2015; Coleman et al., 2015; Morrill et al., 2015). According to Bielmann et al. (2010), a digital refractometer can determine the IgG content in colostrum measured by RID with a correlation of $\mathrm{r}=0.71$ and acceptable test sensitivities and specificities. In our study there was only a weak correlation between sandwich ELISA and Brix refractometry $(\mathrm{r}=0.44)$. Obviously, results obtained by sandwich ELISA and RID cannot be directly compared (Dunn et al., 2017). Therefore, the results in our study generated by sandwich ELISA limits the comparability with other studies using RID. It remains speculative why there was only poor agreement between the 2 methods. According to Elsohaby et al. (2017), variations in the correlation coefficients could be related to the different non-IgG components in colostrum. The measurement via Brix refractometry assesses IgG concentrations indirectly, through assessing total dissolved solids that affect the sucrose concentration. These are affected by dry period length (Rastani et al., 2005), vaccination status of the dam (Hodgins and Shewen, 1996), and season of calving (Morin et al., 2001). Further research is needed to compare the different analytical methods.

\section{Parity}

According to Gulliksen et al. (2008), the concentration of colostral $\operatorname{IgG}$ increases with increasing parity until reaching the fourth lactation. Older cows seemed to produce colostrum with higher IgG concentrations, being exposed to antigens for a longer time during their life than younger cows. Antibodies are transferred from serum into colostrum and the colostral IgG concentration increases with the number of lactations. Consequently, the parity itself had a positive influence on colostrum quality (Conneely et al., 2013). In our study, primiparous cows and cows in 2nd parity had lower colostrum quality determined by both methods compared with older cows, which is consistent with previous studies (Pritchett et al., 1991; Gulliksen et al., 2008). Van Saun and Sniffen (2014) recommended prepartum feeding diets with at least $>1,100 \mathrm{~g} / \mathrm{d}$, with $1,300 \mathrm{~g} / \mathrm{d}$ of MP being better amount. The feeding diet in the present study was slightly above $1,100 \mathrm{~g} / \mathrm{d}(1,189$ $\mathrm{g} / \mathrm{d}$ ), but below the $1,300 \mathrm{~g} / \mathrm{d}$ recommendation, which might explain the weak percentage $(48 \%)$ of high quality colostrum found. Furthermore, it might explain the poor performance of $2 \mathrm{nd}$ parity cows. As $41 \%$ of colostral samples drawn from primiparous cows exceeded the cutpoint of $50 \mathrm{mg}$ of $\mathrm{IgG} / \mathrm{mL}$, it is worthwhile to measure colostrum quality on farm and discard only the low quality colostrum.

\section{Calf Birth Weight and Gestation Length}

We observed a positive association between calf birth weight and colostrum quantity. Gestation length and calf birth weight may be positively correlated with colostrum quantity or related to the dam's BW. Gestation length and calf birth weight are related, since the growth of the fetus in the last trimester of gestation increases considerably (Van Saun and Sniffen, 2014). In the present study, the correlation coefficient of gestation length and calf birth weight was $\mathrm{r}=0.49$. According to Karl and Staufenbiel (2016), the average IgG concentration in colostrum depends on gestation length. Cows up to 275 d gestation length had a colostral IgG concentration of $51.8 \mathrm{mg} / \mathrm{mL}$, whereas cows with 276 to $285 \mathrm{~d}$ had $25.6 \mathrm{mg} / \mathrm{mL}$ and cows with more than $285 \mathrm{~d}$ had $26.2 \mathrm{mg} / \mathrm{mL}$ (Karl and Staufenbiel, 2016). The average IgG concentration in our study was $54.4 \mathrm{mg} / \mathrm{mL}$ for cows with a gestation length of $265 \mathrm{up}$ to $275 \mathrm{~d}(\mathrm{n}=191), 55.6 \mathrm{mg} / \mathrm{mL}$ for cows with 276 to 285 gestation days $(\mathrm{n}=273)$, and $49.3 \mathrm{mg} / \mathrm{mL}$ for cows with 286 to 289 gestation days $(\mathrm{n}=34)$.

Furthermore, BW of the dam is associated with calf weight at birth (Berry et al., 2004). As BW is also associated with milk quantity, it might also affect colostrum quantity (Berry et al., 2004; Conneely et al., 2013). While BW of the cows was not measured in this study, it might be an explanation for this association.

In addition, bovine placental lactogen, a hormone produced by the syncytiotrophoblasts of the placenta, correlates with calf birth weight and milk yield in singleton cows (Patel et al., 1996). A stronger secretion capacity of bovine placental lactogen in certain cows could affect calf birth weight and colostrum quantity, but the reason for this difference remains speculative.

\section{Calving Time, Harvesting Time, and Day of Calving}

A positive association between calving time and colostrum quantity, as well as $\operatorname{IgG}$ concentration in colostrum, was detected. Cows calving during the night had the highest quantity and IgG concentration of colostrum compared with cows calving in the morning or afternoon. We speculate that our results were the outcome of lower stress levels of the cows calving at night. During the night, far fewer farm activities occurred and the noise level was significantly reduced. In addition, we observed higher IgG concentration in colostrum, if calving and harvesting of colostrum took place on Sundays. Again, we speculate that lower stress levels of cows calving on Sundays could be the possible explanation for this observation. This finding needs to be validated with a multicentric study design. 
In agreement with previous studies (Moore et al., 2005; Morin et al., 2010), the IgG concentration in colostrum was negatively associated with the interval from calving to colostrum collection. A longer time lag between calving and milking reduced the $\operatorname{IgG}$ concentration in colostrum. According to Morin et al. (2010) the colostral IgG concentration decreases $3.7 \%$ per hour after calving.

The study was conducted during fall and winter with mean ambient temperatures of 9,7 , and $4^{\circ} \mathrm{C}$ in October, November, and December, respectively. The exposure of cattle to high ambient temperatures during late pregnancy has been associated in different studies with poorer colostrum composition, including lower mean concentrations of colostral IgG and IgA, and other components, such as total protein, casein, lactalbumin, fat, and lactose (Godden, 2008). The negative effects of heat stress may influence DMI, resulting in nutritional restriction. Furthermore, a reduced mammary blood flow causes impaired transfer of IgG and nutrients from the blood stream to the udder, or impaired immune reactivity of mammary gland plasmacytes that produce IgA (Godden, 2008; Tao and Dahl, 2013). Part of the included animals were exposed to higher ambient temperatures during late pregnancy. Resulting heat stress could have affected colostrum quality, which could explain the low percentage of high quality colostrum found (48\%). However, this remains an assumption because heat stress parameters were not assessed in the present study.

\section{Study Limitations}

The study was carried out on only one farm. According to Sargeant et al. (2010), a randomized trial conducted at a single site may not be representative of the variety of possible clinical situations. External validity in the present study is limited. Therefore, the results need to be validated with a multicentric study design. Also, the 3 treatment procedures were not randomly allocated on a cow basis but on a daily basis. This approach was chosen to increase compliance with farm employees. We are aware that a random allocation of each cow to 1 of the 3 groups would have been more robust. Based on previous experience, however, we assumed that a study design with a random allocation on a cow basis would have reduced compliance significantly. Furthermore, in the present study 2 treatment procedures (OXY and CA) were compared with a CON group. The option of an i.m. application of saline solution as a placebo in the CON group was rejected, which is an obvious study limitation. A study design with a second control group considering the application of a placebo might have enhanced the comparison of the different treatment procedures.

\section{CONCLUSIONS}

Overall, none of the treatment procedures improved colostrum quantity. However, the administration of parental oxytocin and presence of the calf increased IgG concentration in colostrum of cows compared with the control group. The external validity in our study is limited; therefore, the results should be validated with a multicentric study design. Future studies should involve several farms to increase external validity and measure the biological effect of the treatments (i.e., assessing the serum total protein, the IgG concentration of calves, or the health effects by evaluating clinical signs of calves).

\section{ACKNOWLEDGMENTS}

The authors thank the collaborating farm and the farm personnel for their kind support. We greatly appreciate the support of MSD (Haar, Germany) for the ELISA testing and Dairytop (Beilen, the Netherlands) for providing the Misco Brix refractometer. Franziska Sutter was funded in part by Tiergyn e. V. (Berlin, Germany).

\section{REFERENCES}

Akers, R. M., and A. M. Lefcourt. 1982. Milking and suckling induced secretion of oxytocin and prolactin in parturient dairy cows. Horm. Behav. 16:87-93.

Bartier, A. L., M. C. Windeyer, and L. Doepel. 2015. Evaluation of on-farm tools for colostrum quality measurement. J. Dairy Sci. 98:1878-1884. https://doi.org/10.3168/jds.2014-8415.

Baumrucker, C. R., A. M. Burkett, A. L. Magliaro-Macrina, and C. D. Dechow. 2010. Colostrogenesis: Mass transfer of immunoglobulin G1 into colostrum. J. Dairy Sci. 93:3031-3038.

Berry, D. P., R. Buckley, P. Dillon, R. D. Evans, and R. R. Veerkamp. 2004. Genetic relationships among linear type traits, milk yield, body weight, fertility and somatic cell count in primiparous dairy cows. Ir. J. Agric. Food Res. 43:161-176.

Bielmann, V., J. Gillan, N. R. Perkins, A. L. Skidmore, S. Godden, and K. E. Leslie. 2010. An evaluation of Brix refractometry instruments for measurement of colostrum quality in dairy cattle. J. Dairy Sci. 93:3713-3721.

Bruckmaier, R. M., and J. W. Blum. 1996. Simultaneous recording of oxytocin release, milk ejection and milk flow during milking of dairy cows with and without prestimulation. J. Dairy Res. 63:201208.

Bruckmaier, R. M., and J. W. Blum. 1998. Oxytocin release and milk removal in ruminants. J. Dairy Sci. 81:939-949.

Coleman, L. W., R. E. Hickson, J. Amoore, R. A. Laven, and P. J. Back. 2015. Colostral immunoglobulin G as a predictor for serum immunoglobulin G concentration in dairy calves. Proc. N.Z. Soc. Anim. Prod. 75:3-8.

Conneely, M., D. P. Berry, R. Sayers, J. P. Murphy, I. Lorenz, M. L. Doherty, and E. Kennedy. 2013. Factors associated with the concentration of immunoglobulin $\mathrm{G}$ in the colostrum of dairy cows. Animal 7:1824-1832. https://doi.org/10.1017/S1751731113001444. 
de Passillé, A. M., J. Rushen, and P. G. Marnet. 1997. Effects of nursing a calf on milk ejection and milk yield during milking. J. Dairy Sci. 80(Suppl. 1):203. (Abstr.)

Dohoo, I. R., S. W. Martin, and H. Stryhn. 2009. Model-building strategies. Veterinary Epidemiologic Research. 2nd ed. VER Inc., Charlottetown. PEI. Canada. 2009:365-390.

Dunn, A., C. Duffy, A. Gordon, S. Morrison, A. Argüello, M. Welsh, and B. Earley. 2017. Comparison of single radial immunodiffusion and ELISA for the quantification of immunoglobulin $\mathrm{G}$ in bovine colostrum, milk and calf sera. J. Appl. Anim. Sci. 46:758-765. https://doi.org/10.1080/09712119.2017.1394860.

Elsohaby, I., J. T. McClure, M. Cameron, L. C. Heider, and G. P. Keefe. 2017. Rapid assessment of bovine colostrum quality: How reliable are transmission infrared spectroscopy and digital and optical refractometers? J. Dairy Sci. 100:1427-1435. https://doi.org/ $10.3168 /$ jds.2016-11824.

Erhard, M. H., P. Amon, S. Nüske, and M. Stangassinger. 1999. Studies on the systemic availability of maternal and endogeneously produced immunoglobulin G1 and G2 in newborn calves by using newly developed ELISA systems. J. Anim. Physiol. Anim. Nutr. (Berl.) 81:239-248.

Faber, S. N., N. E. Faber, T. C. McCauley, and R. L. Ax. 2005. Case Study: Effects of colostrum ingestion on lactational performance. Prof. Anim. Sci. 21:420-425.

Fleenor, W. A., and G. H. Stott. 1981. Single radial immunodiffusion analysis for quantitation of colostral immunoglobulin concentration. J. Dairy Sci. 64:740-747.

Godden, S. 2008. Colostrum management for dairy calves. Vet. Clin. North Am. Food Anim. Pract. 24:19-39.

Godden, S. 2017. Management of the newborn calf. Pages 399-408 in Large Dairy Herd Management. 3rd ed. D. K. Beede, ed. American Dairy Science Association, Champaign, IL.

Gulliksen, S. M., K. I. Lie, L. Sølverød, and O. Østera. 2008. Risk factors associated with colostrum quality in Norwegian dairy cows. J. Dairy Sci. 91:704-712.

Hodgins, D. C., and P. E. Shewen. 1996. Preparturient vaccination to enhance passive immunity to the capsular polysaccharide of Pasteurella haemolytica A1. Vet. Immunol. Immunopathol. 50:67-77.

Karl, M., and R. Staufenbiel. 2016. Investigation of influence factors on quantity of first colostrum in Holstein Friesian cows and their relation to postpartum calcium concentration. Tierärztl. Prax. Ausg G 44:345-354. https://doi.org/10.15653/TPG-150855.

Kehoe, S. I., A. J. Heinrichs, M. L. Moody, C. M. Jones, and M. R. Long. 2011. Comparison of immunoglobulin G concentrations in primiparous and multiparous bovine colostrum. Prof. Anim. Sci. $27: 176-180$.

Kertz, A. F., T. M. Hill, J. D. Quigley, A. J. Heinrichs, J. G. Linn, and J. K. Drackley. 2017. A 100-Year Review: Calf nutrition and management. J. Dairy Sci. 100:10151-10172. https://doi.org/10 $.3168 /$ jds.2017-13062.

Lupoli, B., B. Johansson, K. Uvnäs-Moberg, and K. SvennertsenSjaunja. 2001. Effect of suckling on the release of oxytocin, prolactin, cortisol, gastrin, cholecystokinin, somatostatin and insulin in dairy cows and their calves. J. Dairy Res. 68:175-187.

Mačuhová, J., V. Tančin, and R. M. Bruckmaier. 2004. Effects of oxytocin administration on oxytocin release and milk ejection. J. Dairy Sci. 87:1236-1244.

McGuirk, S. M., and M. Collins. 2004. Managing the production, storage, and delivery of colostrum. Vet. Clin. North Am. Food Anim. Pract. 20:593-603. https://doi.org/10.1016/j.cvfa.2004.06.005.

Moore, M. P., J. W. Tyler, M. Chigerwe, M. E. Dawes, and J. R. Middleton. 2005. Effect of delayed colostrum collection on colostral IgG concentration in dairy cows. J. Am. Vet. Med. Assoc. 226:1375-1377.

Morin, D. E., P. Constable, F. Maunsell, and G. McCoy. 2001. Factors associated with colostral specific gravity in dairy cows. J. Dairy Sci. 84:937-943

Morin, D. E., S. V. Nelson, E. D. Reid, D. W. Nagy, G. E. Dahl, and P. D. Constable. 2010. Effect of colostral volume, interval between calving and first milking, and photoperiod on colostral IgG concentration in dairy cows. J. Am. Vet. Med. Assoc. 237:420-428.
Morrill, K. M., E. Conrad, A. Lago, J. Campbell, J. Quigley, and H. Tyler. 2012. Nationwide evaluation of quality and composition of colostrum on dairy farms in the United States. J. Dairy Sci. 95:3997-4005.

Morrill, K. M., K. E. Robertson, M. M. Spring, A. L. Robinson, and H. D. Tyler. 2015. Validating a refractometer to evaluate immunoglobulin G concentration in Jersey colostrum and the effect of multiple freeze-thaw cycles on evaluating colostrum quality. J. Dairy Sci. 98:595-601. https://doi.org/10.3168/jds.2014-8730.

Nostrand, S. D., D. M. Galton, H. N. Erb, and D. E. Bauman. 1991. Effects of daily exogenous oxytocin on lactation milk yield and composition. J. Dairy Sci. 74:2119-2127.

NRC. 2001. Nutrient Requirements of Dairy Cattle. 7th rev. ed. Natl. Acad. Press, Washington, DC.

Nowak, W., R. Mikula, A. Zachwieja, K. Paczynska, E. Pecka, K. Drzazga, and P. Slosarz. 2012. The impact of cow nutrition in the dry period on colostrum quality and immune status of calves. Pol. J. Vet. Sci. 15:77-82.

Patel, O. V., M. Hirako, T. Takahashi, N. Sasaki, and I. Domeki. 1996. Plasma bovine placental lactogen concentration throughout pregnancy in the cow; relationship to stage of pregnancy, fetal mass, number and postpartum milk yield. Domest. Anim. Endocrinol. 13:351-359.

Pritchett, L. C., C. C. Gay, T. E. Besser, and D. D. Hancock. 1991. Management and production factors influencing immunoglobulin G1 concentration in colostrum from Holstein cows. J. Dairy Sci. 74:2336-2341.

Rastani, R. R., R. Grummer, S. Bertics, A. Gümen, M. Wiltbank, D. Mashek, and M. Schwab. 2005. Reducing dry period length to simplify feeding transition cows: Milk production, energy balance, and metabolic profiles. J. Dairy Sci. 88:1004-1014.

Rivero, M. J., X. Valderrama, D. Haines, and D. Alomar. 2012. Prediction of immunoglobulin $\mathrm{G}$ content in bovine colostrum by nearinfrared spectroscopy. J. Dairy Sci. 95:1410-1418.

Sargeant, J. M., A. M. O'Connor, I. A. Gardner, J. S. Dickson, M. E. Torrence, I. R. Dohoo, S. L. Lefebvre, P. S. Morley, A. Ramirez, and K. Snedeker. 2010. The REFLECT statement: Reporting guidelines for Randomized Controlled Trials in livestock and food safety: Explanation and elaboration. Zoonoses Public Health $57: 105-136$.

Schuenemann, G. M., I. Nieto, S. Bas, K. N. Galvão, and J. Workman. 2011. Assessment of calving progress and reference times for obstetric intervention during dystocia in Holstein dairy cows. J. Dairy Sci. 94:5494-5501. https://doi.org/10.3168/jds.2011-4436.

Soberon, F. E. Raffrenato, R. W. Everett, and M. E. Van Amburgh. 2012. Preweaning milk replacer intake and effects on long-term productivity of dairy calves. J. Dairy Sci. 95:783-793. https://doi .org/10.3168/jds.2011-4391.

Stelwagen, K., and K. Singh. 2014. The role of tight junctions in mammary gland function. J. Mammary Gland Biol. Neoplasia 19:131138. https://doi.org/10.1007/s10911-013-9309-1.

Tančin, V., W. D. Kraetzl, D. Schams, and R. M. Bruckmaier. 2001. The effects of conditioning to suckling, milking and of calf presence on the release of oxytocin in dairy cows. Appl. Anim. Behav. Sci. $72: 235-246$

Tao, S., and G. E. Dahl. 2013. Invited review: Heat stress effects during late gestation on dry cows and their calves. J. Dairy Sci. 96:4079-4093. https://doi.org/10.3168/jds.2012-6278.

Van Saun, R. J., and C. J. Sniffen. 2014. Transition cow nutrition and feeding management for disease prevention. Vet. Clin. North Am. Food Anim. Pract. https://doi.org/10.1016/j.cvfa.2014.07.009.

Vandeputte, S., J. Detilleux, and F. Rollin. 2014. Investigation of colostrum quality in beef cattle by radial immunodiffusion and brix refractometry. Vet. Rec. 175:353. https://doi.org/10.1136/vr .101590.

Weaver, D. M., J. W. Tyler, D. C. VanMetre, D. E. Hostetler, and G. M. Barrington. 2000. Passive transfer of colostral immunoglobulins in calves. J. Vet. Intern. Med. 14:569-577.

Wellnitz, O., and R. M. Bruckmaier. 2001. Central and peripheral inhibition of milk ejection. Livest. Prod. Sci. 70:135-140. 